\title{
Attitude of healthcare students towards HIV/ AIDS and people living with HIV in selected dental and nursing colleges at Chennai, India
}

\author{
Lathamangeswari Chinnasamy ${ }^{1}$, Akila Muthukrishnan ${ }^{2}$ \\ ${ }^{1}$ Jothi College of Management Science \& Technology, Bareilly, Uttar Pradesh, India \\ ${ }^{2}$ School of Nursing, College of Pharmacy and Nursing, University of Nizwa, Sultanate of Oman
}

\begin{abstract}
Introduction: The healthcare personnel and people living with human immunodeficiency virus (HIV)/acquired immunodeficiency syndrome (AIDS) need to understand each other for advancement of healthcare delivery system. The attitude of healthcare people contributes a lot to achieve good practices towards the same people who are in deliberate need of support for their living. The aim of this study was to assess the attitude of 600 healthcare students in dental and nursing colleges towards HIV/AIDS and people living with HIV infection (PLHIV), and associate the attitude with demographic data.

Material and methods: A quantitative study was carried out to obtain information from 600 healthcare students of six nursing and three dental colleges in Chennai, India to assess the level of attitude regarding HIV and PLHIV. Non-probability convenient sampling technique with simple randomization was used for the selection of samples. Reliability of tool was assessed by test-retest method, as $r=0.7$, and content validity was obtained from the experts. The collected data was analyzed by using SPSS package version 22.0.

Results: Among 600 participants, 53\% had negative attitude, $29 \%$ had moderately positive attitude, and $18 \%$ had positive attitude towards taking care of HIV-infected people. The mean score was 18.91 (range, 0-60) with standard deviation of \pm 13.07 . Their attitude level was significantly associated with the source of information about HIV/AIDS, but not with the other demographic variable such as age, gender, family income, and parents' occupation.

Conclusions: Healthcare students are in need of intense teaching program with various methods, which can change their attitude to eliminate the fear and stigma towards HIV/AIDS and taking care of people living with HIV/AIDS.
\end{abstract}

HIV AIDS Rev 2020; 19, 1: 43-48 DOI: https://doi.org/10.5114/hivar.2020.93234

Key words: AIDS, antiretroviral treatment, HIV prevention, healthcare society, stigma.

\section{Introduction}

Human immunodeficiency virus (HIV) infection and acquired immunodeficiency syndrome (AIDS) remains a leading cause of ill-health and mortality. Today, more

than one million Americans are infected with the virus [1]. African countries such as Ethiopia, Kenya, and Zimbabwe represent $30-60 \%$ of their total health ministry budget on HIV/AIDS [2]. In Asia and the Pacific region, five million people are living with HIV, approximately 3.4 million people

Article history:

Received: 31.03.2019

Received in revised form: 27.05.2019

Accepted: 05.07.2019

Available online: 16.02 .2020
International Journal of HIV-Related Problems

HIV \& AIDS

R e v i e w 
were reported with new HIV infections, and 240,000 people died of AIDS-related causes in 2014 [3]. In Asia, 51\% of AIDS-related deaths occurred in 2013 and $8 \%$ of deaths worldwide [4]. Also, between 2000 and 2014, the number of AIDS-related deaths increased by $11 \%$. However, the treatment coverage is only for $36 \%$ of all people living with HIV in Asia and the Pacific region [3]. On the other hand, Indonesia and India account for $78 \%$ of new HIV infections. National AIDS Control Organization (NACO announced that in India, HIV prevalence among gay men was $4 \%$ to $9 \%$ [5]. HIV/AIDS has major effect on the economic growth of a country, as the young age group (15-24) is getting affected [6].

The World Bank in a report from 2015 stated that by 2020 , India will have to spend $7 \%$ of its health budget on AIDS due to the rising tide of AIDS epidemic in North, Northeast, and South India, which would place a further strain on a struggling health sector [7]. Ten years back, in South Indian states such as Tamil Nadu, there was an alarmingly high incidence of HIV infection, which eventually dropped down from third to fifth place among the states [8]. HIV infection is considered as one of the most deadly infection; once the virus enters the human body, it stays permanently. As per the current status, there is no cure to this infection, but with a proper treatment and medical care, HIV infection can be controlled by keeping the carrier individuals clinically healthy, thereby lowering their chances of transmitting the virus to others. It is estimated that a 20 -year-old man with HIV who begins treatment early can expect to live up to 77 years, which is the average lifespan of an American.

HIV-positive person with modern anti-retroviral therapy can reduce the chances of transmitting the virus by $96 \%$. People living with HIV are very frequent visitors in healthcare sector, hence the World Health Organization (2015) [9] announced as "any person enters the healthcare system is potentially positive for HIV”. Aggarwal and Panat stated that an increasing number of HIV-infected individuals are receiving oral dental care in India [10]. Guruprasad and Chauhan reported that dental students who often use sharp instruments and are handling blood of HIV patients, are those who are the most vulnerable to HIV exposure [11]. Taking care of HIV-infected persons have been a challenging task in today's scenario. Various healthcare professionals are involved in handling these individuals who often go unnoticed. Moreover, the attitude of healthcare providers remains with mixed feeling of doubts and queries. The fear of stigma attached to HIV/AIDS may prevent people from having an HIV test, seeking treatment, and acknowledging their own HIV status [12]. Ideally, these individuals should be able to come out openly with a positive thoughts to disclose HIV infection, but current attitudes of healthcare professionals towards HIV/AIDS individuals make them reluctant to reveal the problem. In view of the above, the aim of our study was to assess the attitude of 600 healthcare students (HCS) from dental and nursing colleges towards HIV/ AIDS and people living with HIV (PLHIV), and associate the attitude with demographic data.

\section{Material and methods}

This descriptive, quantitative study was conducted from January 2016 to April 2016 in six nursing colleges and three dental colleges in Chennai, India. The prior consent was taken from a principal of each college. Through a simple random sampling method, 651 students from the first year BDS and Basic B.Sc. Nursing were recruited for the study. Among them, 34 students were not willing to participate and 17 had already attended the formal education program in HIV/AIDS, hence, they were excluded from the study. Finally, 600 students participated. The Meenakshi Institutional Ethical Committee (MADC/IEC/003/2016) approved the study protocol.

Verbal explanation about this study was given to the students and written consent was obtained. Code numbers were given to maintain anonymity of the students. The demographic details of the students such as age, sex, parent's occupation, family income, and source of information about HIV/AIDS were recorded. The attitude level of the students was assessed by using structured AIDS attitude assessment scale (AAAS) $[13,14]$. It consisted of 15 questions from the HIV knowledge attitude perception (KAP) questionnaire formulated by Magazine and Silas et al. $[13,14]$, which were selected and modified according to the sensitivity of the student group and cultural value. Reliability of tool was tested by test-retest method, as $r=0.7$, and content validity was obtained from the experts.

The total score of AAAS ranges from 0 to 60 and has three subscale scores such as 0-20 negative attitude, 21-40 moderately positive attitude, and 41-60 strongly positive attitude. The students were asked whether they agree or disagree with each question by using a 5-point Likert's scale of strongly agree, agree, disagree, or strongly disagree and undecided. Positive attitude statements were coded with strongly disagree $=1$ to strongly agree $=4$ and negative attitude statements were the reverse, with undecided $=0$. The structured AAAS were distributed to all the students and asked to mark an answer. The participants were given 20 minutes to complete the questionnaires and the data was collected. The students were encouraged to clear any doubt in the AAAS with the investigator.

\section{Statistical analysis}

Descriptive and inferential statistics were used for analyzing data with statistical package for social sciences (SPSS version 22.0). The $p$-value of $<0.05$ was considered to be significant.

\section{Results}

Table 1 shows that all the 600 participants were within the age group of $18-23$ (mean, SD $19.25 \pm 1.21$ ) years, out of which $33 \%$ were male and $67 \%$ were female. Parents of $38 \%$ and $25 \%$ of the students were doing business and daily wages, respectively. With regards to the family monthly income, $47 \%$ of participants parents had income of Rs $>30,000$, $41 \%$ had income of Rs 10,000-20,000 (mean, SD 24,050.56 \pm 
1,255.47). Around 56\% of the students received information regarding HIV/AIDS through web, media, and newspaper, $39 \%$ through friends, 3\% through parents, and 2\% through the teachers. Among the healthcare students (Table 2), $65 \%$ of them strongly agreed that homosexuality should be considered illegal. At the same time, $61 \%$ of them agreed that a patient with AIDS has the right to obtain the same quality of care as any other patient, and 58\% of them agreed to do something to make life easier for people with AIDS.

Among 600 participants (Table 3), 53\% had negative attitude, $29 \%$ had moderately positive attitude, and $18 \%$ had positive attitude for taking care of HIV-infected people. The mean score was 18.91 (range, 0-60) with standard deviation of 13.07 .

Healthcare student's attitude level was significantly associated with source of information about HIV/AIDS, but not with the other demographic variable such as age, gender, family income, and parents' occupation (Table 4).

\section{Discussion}

All the 600 participants were within the age group of 18-23 years. This age group of people are very curious and
Table 1. Distribution of demographic variables among healthcare students $(N=600)$

\begin{tabular}{l|c}
\hline Variables & \\
\hline Age (in years), mean (SD); range & $19.25 \pm 1.21 ; 18-23$ \\
\hline Gender, $n(\%)$ & $196(33)$ \\
\hline Male & $404(67)$ \\
\hline Female
\end{tabular}

Sources of information, $n$ (\%)

\begin{tabular}{l|c}
\hline Web/Media/Newspaper/Books & $336(56)$ \\
\hline Teacher & $12(2)$ \\
\hline Parents & $18(3)$ \\
\hline Friends & $234(39)$ \\
\hline
\end{tabular}

Parents' occupation, $n$ (\%)

\begin{tabular}{l|c}
\hline Daily wages & $153(25)$ \\
\hline $\begin{array}{l}\text { Professionals (teaching, medical, } \\
\text { paramedical, engineering, etc.) }\end{array}$ & $218(36)$ \\
\hline Business & $229(38)$ \\
\hline Family income/month (in rs) & $\begin{array}{c}24,050.56 \pm 1,255.47 ; \\
10,000->30,000\end{array}$ \\
\hline
\end{tabular}

Table 2. Level of attitude of healthcare students about HIV/AIDS and PLHIV

\begin{tabular}{|c|c|c|c|c|c|}
\hline Criteria & $\begin{array}{l}\text { Strongly } \\
\text { agree }\end{array}$ & Agree & Disagree & $\begin{array}{l}\text { Strongly } \\
\text { disagree }\end{array}$ & Undecided \\
\hline $\begin{array}{l}\text { Patients who are only HIV-positive (without any other } \\
\text { diseases) can be treated in rooms with other patients }\end{array}$ & - & $30(5 \%)$ & $168(28 \%)$ & $270(45 \%)$ & $132(22 \%)$ \\
\hline $\begin{array}{l}\text { It is especially important to work with patients with AIDS } \\
\text { in a caring manner }\end{array}$ & - & $33(6 \%)$ & $306(51 \%)$ & $96(16 \%)$ & $165(27 \%)$ \\
\hline $\begin{array}{l}\text { If I am taking care of a HIV-infected patient, I am worried } \\
\text { about the spread of the infection to my family and friends }\end{array}$ & $168(28 \%)$ & $258(43 \%)$ & $54(9 \%)$ & $12(2 \%)$ & $108(18 \%)$ \\
\hline $\begin{array}{l}\text { HIV-negative children can live with their HIV-positive } \\
\text { parents at home }\end{array}$ & $60(10 \%)$ & $180(30 \%)$ & $234(39 \%)$ & - & $126(21 \%)$ \\
\hline $\begin{array}{l}\text { I feel more sympathetic towards people who get AIDS from } \\
\text { blood transfusion than those who get it by injected drugs }\end{array}$ & $156(26 \%)$ & $63(11 \%)$ & $96(16 \%)$ & $206(34 \%)$ & $79(13 \%)$ \\
\hline $\begin{array}{l}\text { I think a patient with AIDS has the right to get the same } \\
\text { quality of care as any other patient }\end{array}$ & $132(22 \%)$ & $366(61 \%)$ & $102(17 \%)$ & - & - \\
\hline A HIV-positive woman has got the right to become pregnant & - & $108(18 \%)$ & $186(31 \%)$ & - & $210(35 \%)$ \\
\hline Most people who have AIDS deserve what they get & $52(9 \%)$ & $80(13 \%)$ & $211(35 \%)$ & $165(28 \%)$ & $92(15 \%)$ \\
\hline Homosexuality should be considered illegal & $390(65 \%)$ & $60(10 \%)$ & $72(12 \%)$ & - & $78(13 \%)$ \\
\hline $\begin{array}{l}\text { I think that people who are addicted to injected drugs } \\
\text { deserve to be infected with AIDS }\end{array}$ & $106(18 \%)$ & $83(14 \%)$ & $126(21 \%)$ & $149(25 \%)$ & $136(23 \%)$ \\
\hline $\begin{array}{l}\text { I would like to do something to make life easier for people } \\
\text { with AIDS }\end{array}$ & $90(15 \%)$ & $348(58 \%)$ & $78(13 \%)$ & - & $84(14 \%)$ \\
\hline $\begin{array}{l}\text { Most people who have AIDS have to blame only } \\
\text { themselves }\end{array}$ & $57(10 \%)$ & $52(9 \%)$ & $190(32 \%)$ & $181(30 \%)$ & $120(20 \%)$ \\
\hline $\begin{array}{l}\text { I have a sympathy for people who get AIDS from sexual } \\
\text { contact unknowingly }\end{array}$ & $60(10 \%)$ & $270(45 \%)$ & $120(20 \%)$ & - & $132(25 \%)$ \\
\hline I have a strong fear about HIV-positive people & $78(13 \%)$ & $330(55 \%)$ & $66(11 \%) n$ & - & $126(21 \%) n$ \\
\hline $\begin{array}{l}\text { Patients who are HIV-positive should be treated with } \\
\text { the same respect as any other patients }\end{array}$ & $126(21 \%)$ & 234 (39\%) & $54(9 \%)$ & - & 186 (31\%) \\
\hline
\end{tabular}


Table 3. Mean score of attitude of healthcare students about HIV/AIDS and PLHIV $(N=600)$

\begin{tabular}{l|c|c|c|c}
\hline Level of attitude & No & $\%$ & Mean/SD (range) & Overall mean/SD \\
\hline Negative attitude & 318 & 53 & $17.28 \pm 1.52(0-20)$ & 18.91 \\
\hline Moderately positive attitude & 174 & 29 & $27.14 \pm 2.03(21-40)$ & 13.07 \\
\hline Positive attitude & 108 & 18 & $43.62 \pm 1.48(41-60)$ & \\
\hline
\end{tabular}

Table 4. Association of level of attitude of healthcare students towards patients living with HIV/AIDS with selected demographic variables

\begin{tabular}{|c|c|c|c|c|c|}
\hline \multirow[t]{2}{*}{ Variables } & \multirow[t]{2}{*}{ No } & \multicolumn{3}{|c|}{ Level of attitude } & \multirow{2}{*}{$\underset{p \text {-value }}{\chi^{2}}$} \\
\hline & & Negative & Moderately positive & Positive & \\
\hline \multicolumn{6}{|l|}{ Age (in years) } \\
\hline $18-19$ & 515 & 281 & 144 & 90 & 6.142 \\
\hline $20-21$ & 65 & 30 & 23 & 12 & 0.1887 \\
\hline $22-23$ & 20 & 8 & 10 & 2 & \\
\hline \multicolumn{6}{|l|}{ Gender } \\
\hline Male & 196 & 104 & 62 & 30 & 4.810 \\
\hline Female & 404 & 242 & 94 & 68 & 0.090 \\
\hline \multicolumn{6}{|l|}{ Sources of information } \\
\hline Web/media/newspaper/books & 336 & 172 & 109 & 55 & 35.626 \\
\hline Teacher & 12 & 2 & 8 & 2 & $0.0001^{* * *}$ \\
\hline Parents & 18 & 4 & 10 & 4 & \\
\hline Friends & 234 & 150 & 40 & 44 & \\
\hline \multicolumn{6}{|l|}{ Parents' occupation } \\
\hline Daily wages & 153 & 82 & 47 & 24 & 2.871 \\
\hline $\begin{array}{l}\text { Professionals (teaching, medical, paramedical, } \\
\text { engineering, etc.) }\end{array}$ & 218 & 120 & 55 & 43 & 0.057 \\
\hline Business & 229 & 118 & 72 & 39 & \\
\hline \multicolumn{6}{|l|}{ Family income/month (in rs) } \\
\hline $10,000-20,000$ & 243 & 118 & 83 & 42 & 5.852 \\
\hline $20,001-30,000$ & 78 & 43 & 20 & 15 & 0.210 \\
\hline$>30,000$ & 279 & 162 & 74 & 43 & \\
\hline
\end{tabular}

interested in sexual activities. So, it is suggested that this age group students are more prone to get HIV infection, which is supported by the Joint United Nations Programme on HIV/ AIDS (UNAIDS Report, 2007) [15]. According to Hawkes and Santhya, in India, $23 \%$ of the total population within the age group of 10-19 years fall under the risk of HIV infection [16].

Out of the 600 participants, 33\% were male and $67 \%$ were female. The data suggested that the majority of students opting a healthcare profession such as dentistry and nursing were female. This is in accordance with WD Square who stated that female are more vulnerable to get HIV infection biologically and due to socio-cultural factors such as male domination, domestic violence, child labor, prostitution, and economic abuse. This is also supported by the National AIDS Control Organization Report (NACO) [5]. Among the 600 participants, parents of $38 \%$ students were doing business and $26 \%$ were daily wagers. However, the parent's occupation did not influence the attitude level of students towards taking care of people infected with HIV.

In the present study, $56 \%$ of the students received information regarding HIV/AIDS through web, media, newspaper, and $39 \%$ by friends. This is in accordance with Goel et al. who highlighted that $83 \%$ of the nursing students selected the main source of information as television (TV), newspaper/magazine, and $26 \%$ as peers [17]. Dharmalingam et al. also revealed that nearly three-fourth $(73.8 \%)$ of the nursing students received information about HIV/ AIDS through mass media, TV, newspaper, and magazines [18]. It is suggested that mass media plays a major role in HIV awareness. 
Among the 600 of healthcare students, 53\% had negative attitude towards HIV/AIDS patients (Table 3). This was in accordance with $\mathrm{Li}$ et al. who also demonstrated in their study that $94 \%$ of healthcare students had overall negative attitude towards HIV/AIDS [19]. Horoun et al. found that $85 \%$ of the nursing students expressed negative attitude towards people living with HIV [20]. Dharmalingam et al. and Grover et al. also reported that $32.6 \%$ of nursing students and $43 \%$ of dental students had negative attitude towards HIV/AIDS patients [18,21]. However, Pickles et al. stated that only $4.3 \%$ of Australian second year undergraduate nursing students had negative attitude towards caring for people with HIV/AIDS [22]. However, a significant negative attitude was found among nursing students from China, East, South East, Central, and Middle East Asia than the western countries [23]. Alticeb et al. also reported an attitude difference according to the ethnicity towards HIV-infected people [24]. In contrast to the present study, Aggarwal et al. assessed the HIV/AIDS-related attitude among dental students in the Institute of Dental Sciences, Bareilly (UP), India, and found that $77.7 \%$ had a positive attitude towards HIV-infected persons [25].

The level of attitude of healthcare students did not depend on their age, which was not in accordance with Hamid Albujeer et al. and Jyothi [26,27]. The level of attitude of healthcare did not depend on their parents' occupation and income, but depended on the source of information about HIV/AIDS. The level of attitude of the healthcare students was independent regarding their gender, which was in accordance with Hamid Albujeer et al. [26].

\section{Limitation}

The attitude of the students was assessed by a questionnaire, which was subjective with bias.

\section{Conclusions}

It is suggested that for further educational enrichment, a schooling program in the field of health service regarding the magnitude of HIV infection, the mode of HIV transmission, the nature of disease progression, treatment modality, preventive methods of HIV infection, and the standard protocol for early reporting of needle-stick injuries should be provided. Hence, the healthcare students need an intense teaching program with various education methods, which can change their attitude towards HIV/AIDS and taking care of people living with HIV. The teaching system should be based on the students cultural, moral, and sex values in accordance with their ethnicity.

\section{Conflict of interest}

The authors declare no potential conflicts of interest with respect to the research, authorship, and/or publication of this article.

\section{References}

1. World Report. On Human Rights Watch; 2016. Available at: www. fngis.pt/wp-content/uploads/wr2016.pdf.

2. Centers for Disease Control and Prevention. HIV/AIDS Surveilance, National Center for HIV/AIDS, Viral Hepatitis, Sexual Transmitted Diseases and Tuberculosis Prevention; 2015. Available at: https://www.cdc.gov/nchs/data/nvsr/nvsr64/nvsr64_12.pdf.

3. Centers for Disease Control and Prevention. HIV/AIDS Surveillance Report; 2016. Available at: https://www.cdc.gov/nchs/data/ hus/hus16.pdf.

4. HIV and AIDS in Asia \& the Pacific regional overview; 2020. Available at: https://www.avert.org/professionals/hiv-around-world/ asia-pacific/overview.

5. Global information and education on HIV and AIDS; 2020. https:// www.avert.org/professionals/hiv-around-world/asia-pacific/india.

6. Rani V. Awareness among educated mothers about sexually transmitted disease AIDS. International Journal of Science and Research 2016; 5: 259-260.

7. The World Bank in South Asia; 2015. Available at: www.worldbank. org/en/region/sar/overview.

8. Vasundara R. Fewer new cases, TN 5 th in HIV numbers. Times of India; 2012. Available at: https://timesofindia.indiatimes.com/ city/chennai/Fewer-new-cases-TN-5th-in-HIV-numbers/articleshow/15303505.cms.

9. Global information and education on HIV and AIDS; 2015. https:// www.who.int/news-room/fact-sheets/detail/hiv-aids. Available at: https://www.avert.org/professionals/hiv-around-world/asia-pacific/ overview.

10. Aggarwal A, Panat SR. Knowledge, attitude and behavior in managing patients with HIV/AIDS among a group of Indian dental students. J Dent Educ 2013; 77: 1209-1217.

11. Guruprasad Y, Chauhan DS. Knowledge, attitude and practice regarding risk of HIV infection through accidental needle sticks injuries among dental students of Raichur, India. Natl J Maxillofac Surg 2011; 2: 152-155.

12. Feyissa GT, Abebe L, Girma E, Woldie M. Stigma and discrimination against people living with HIV by healthcare providers, Southwest Ethiopia. BMC Public Health 2012; 12: 522.

13. Magazine R, Chogtu B, Muthukumaran L, Reddy AJS, Srivastava N, Mohapatra AK. Knowledge, attitude and practice of nurses regarding pulmonary tuberculosis in a tertiary care hospital. Indian J Respir Care 2012; 1: 161-166.

14. Lui PSC, Sarangapany J, Begley K, Coote K, Kishore K. Medical and nursing students perceived knowledge, attitudes and practices concerning human immunodeficiency virus. International Scholarly Research Notices 2014; 2014: 975875.

15. UNAIDS. Report on the global AIDS epidemic. UNAIDS, Geneva 2007.

16. Hawkes S, Santhya KG. Diverse realities: sexually transmitted infections and HIV in India. Sex Transm Infect 2002; 78 Suppl 1: i31-39.

17. Naveen KG, Rahul B, Rambha P, Sharma HK, Monika A, Luthra SC. Knowledge and awareness of nursing students about HIV/ AIDS. Health and Population: Perspectives and Issues 2010; 33: 55-60.

18. Dharmalingam M, Poreddi V, Gandhi S, Chandra R. Under graduate nursing students' knowledge and attitude toward people living with human immunodeficiency virus/acquired immunodeficiency syndrome. Int J Adv Med Health Res 2015; 2: 22-27.

19. Li R, Dong W, He W, Liu Y. Chinese dental students "knowledge and attitudes toward HIV/AID. J Dent Sci 2016; 11: 72-78.

20. Haroun D, El Saleh O, Wood L, Mechli R, Al Marzouqi N, Anouti S. Assessing Knowledge of, and Attitudes to, HIV/AIDS among University Students in the United Arab Emirates. PLoS One 2016; 11 : e0149920. 
21. Grover N, Prakash A, Singh S, Singh N, Singh P, NazeerJ. Attitude and knowledge of dental students of National Capital Region regarding HIV and AIDS. J Oral Maxillofac Pathol 2014; 18: 9-13.

22. Pickles D, King L, Belan I. Attitude of student nurses towards caring for people living with HIV: thematic literature review. J Adv Nurs 2009; 65: 2262-2273.

23. Choudhary HA, Ali R, Altaf S. Knowledge, behaviour and attitudes regarding HIV/AIDS among undergraduate students in an Irish University. Int J Surg Med 2015; 1: 58-66.

24. Earnshaw VA, Jin H, Wickersham J, Kamarulzaman A, John J, Altice FL. Exploring intentions to discriminate against patients living with HIV/AIDS among future healthcare providers in Malaysia. Trop Med Int Health 2014; 19: 672-679.

25. Aggarwal A, Panat SR. Knowledge, attitude, and behavior in managing patients with HIV/AIDS among a group of Indian dental students. J Dent Educ 2013; 77: 1209-1217.

26. Hamid Albujeer AN, Shamshiri AR, Taher A. HIV/AIDS awareness among Iraqi medical and dental students. Int Soc Prev Community Dent 2015; 5: 372-376.

27. Jyothi MS. Effectiveness of structured teaching programme on knowledge attitude and behavior on AIDS and its prevention among the pre-university students in selected colleges of Tumkur; 2012. Available at: http://hdl.handle.net/10603/4585. 